\title{
KEANEKARAGAMAN JAMUR BASIDIOMYCOTA DI HUTAN TROPIS DATARAN RENDAH SUMATERA, INDONESIA \\ (Studi Kasus di Arboretum Fakultas Kehutanan Universitas Lancang Kuning Pekanbaru)
}

\author{
Tri Roh Wahyudi ${ }^{1}$, Sri Rahayu $\mathbf{P}^{2}$, Azwin ${ }^{2}$ \\ ${ }^{1}$ Mahasiswa Fakultas Kehutanan Universitas Lancang Kuning \\ ${ }^{2}$ Staf Pengajar Fakultas Kehutanan Universitas Lancang Kuning \\ Jln. Yos Sudarso Km. 8 Rumbai Pekanbaru Riau \\ Email :trirohwahyudi@gmail.com; srirahayupn@unilak.ac.id; azwin@unilak.ac.id
}

\begin{abstract}
Tropical rain forest is one type of forest ecosystem that dominated most of Sumatra areal. Arboretum of Faculty of forestry, Lancang Kuning University is the one of tropical rain forest which the environment becomes a place or habitat for living things. This study aims to describe the various of fungi Basidiomycota. This study was going on May - June 2016. The making technique of data by exkplore an arboretum area to straight saw the fungi. The data collected were characteristic of fungi by morphology and detail pictue to indentification. The result shows that there are 25 species include in 12 families. Species that is Auricularia auricula, Schyzophylum commune, Ramariopsis kunzei, Agaricus crocopeplus, Lepiota sp, Lycoperdon Pyriforme, Crepidotus sp, Mycena incata, Mycena sp, Marasmieullus candidus, Marasmius andracaceus, Marasmius elegan, Marasmius sp1, Marasmius $s p 2$, Collybia sp, Polyporus sp, Lignosus rhinocerus, Ganoderma aplanatum, Ganoderma sp, Fomitopsis cajanderi, Fomitopsis finicola, Grivola Frondosa, Grivola $s p$, Coltricia perennis dan Coltricia cinamomea. The number of fungi order were 5 (five) that could be Auriculateales, Aphylloporales, Agaricales, Polyporales and Hymenochaetales.
\end{abstract}

Keywords : Basidiomycota, species, the tropical rain forest

\section{PENDAHULUAN}

Indonesia memiliki hutan hujan tropis terluas ketiga setelah Brazil dan Kongo mulai dari ekosistem pantai, dataran rendah sampai dengan dataran tinggi atau pegunungan. Hutan hujan tropis merupakan tempat tinggal bagi keanekaragaman spesies flora dan fauna termasuk jamur dimana keanekaragaman jamur menempati urutan ke 2 setelah serangga. Jumlah spesies jamur yang telah ditemukan sebanyak \pm 69.000 dari perkiraan 1.500.000 spesies jamur di dunia. Mengingat lingkungan hutan yang lembab dan suhu tropis yang 
mendukung pertumbuhan jamur, maka dapat dipastikan bahwa Indonesia mempunyai keanekaragaman jamur yang sangat tinggi.

Jamur banyak ditemukan pada musim penghujan pada kayu lapuk, seresah maupun menjadi parasit pada tumbuhan yang masih hidup. Dari sisi ekologi, jamur di dalam hutan berperan sebagai dekomposer (saprofit) bersama dengan bakteri dan beberapa spesies protozoa, sehingga banyak membantu proses dekomposisi bahan organik untuk mempercepat siklus materi dalam ekosistem hutan. Dengan demikian, jamur ikut membantu menyuburkan tanah melalui penyediaan nutrisi bagi tumbuhan sehingga hutan tumbuh dengan subur (Suharna, 1993 dalam Tampubolon 2010). Beberapa jenis jamur Basidiomycota juga hidup bersimbiosis dengan akar tumbuhan membentuk mikoriza yang berperan dalam membantu pertumbuhan tanaman (Hiola, 2011). Jamur, khususnya kelompok Basidiomycota, merupakan kelompok utama organisme pendegradasi lignoselulosa karena mampu menghasilkan enzim-enzim pendegradasi lignoselulosa seperti selulase, ligninase, dan hemiselulase (Munir, 2006), sehingga siklus materi di alam dapat terus berlangsung. Sejumlah 200.000 spesies dari 1,5 juta spesies jamur diperkirakan ditemukan di Indonesia, dimana hingga saat ini belum ada data pasti mengenai jumlah spesies jamur tersebut, yang telah berhasil diidentifikasi, dimanfaatkan, ataupun yang telah punah akibat ulah manusia (Gandjar et al., 2006 dalam Hayati 2013).

Jamur Basidiomycota adalah jamur yang dapat dilihat secara kasat mata karena ukuran basidiokarpnya (tubuh buah) yang besar. Basidiomycota merupakan jenis jamur dengan basidiokarp yang tumbuh dalam aneka bentuk, warna dan ukuran. Dari aneka jamur Basidiomycota yang dapat ditemukan ada yang menguntungkan dan ada yang merugikan bagi manusia. Beberapa contoh jamur yang menguntungkan seperti Volvariella volvaceae (jamur merang), Auricularia auricula (jamur kuping), dan Schleroderma citrinum dimana jamur tersebut dibudidayakan dan dimanfaatkan sebagai bahan makanan dan obat-obatan. Sedangkan contoh jamur yang merugikan manusia salah satunya adalah Amanita sp, karena menghasilkan racun sehingga dapat 
menyebabkan keracunan bagi yang memakannya.

Arboretum Fakultas Kehutanan Universitas Lancang Kuning merupakan hutan milik Fakultas Kehutanan, Universitas Lancang Kuning. Luas arboretum $\pm 9.3 \mathrm{ha}$, dengan suhu udara rata-rata $25-26^{\circ} \mathrm{C}$, kelembaban udara rata-rata $\pm 80-90 \%$, dan $\mathrm{pH}$ tanah 5.4 - 6.6, ketebalan serasah berkisar antara $0-23 \mathrm{~cm}$. Lokasi arboretum terletak pada ketinggian 19-29 m dpl dengan ketinggian rata-rata $24 \mathrm{~m}$ dpl dengan topografi datar dan berbukit dan tergenang air di beberapa daerah (Anggraini, 2007). Kondisi lingkungan arboretum tersebut sangat mendukung untuk pertumbuhan jamur terutama jamur Basidiomycota karena jamur dapat tumbuh dengan $\mathrm{pH}$ optimum antara 5,57,5 dan kelembaban relatif sebesar 8090\% (Gunawan, 2001 dalam Syafrizal, 2014). Saat ini, Fakultas Kehutanan Universitas Lancang Kuning sedang mengumpulkan data flora, fauna termasuk keanekaragaman jamur yang ada di arboretum. Tujuan dari penelitian ini adalah memberikan informasi tentang potensi jamur Basidiomycota di arboretum tersebut.

\section{METODE PENELITIAN}

Penelitian ini dilakukan di hutan hujan tropis dataran rendah yang lokasinya berada di arboretum Fakultas Kehutanan Universitas Lancang Kuning Pekanbaru, Riau pada bulan Mei - Juni 2016. Berdasarkan hasil pengukuran faktor lingkungan, $\mathrm{pH}$ tanah 5,6 sd 6,5 dengan suhu rata-rata $32-32^{\circ} \mathrm{C}$, kelembaban $74-87 \%$ dan intensitas cahaya 165 sd 933 lux atau $8-47 \%$.

Alat-alat yang di gunakan dalam penelitian ini adalah GPS (Global Positioning System), termohigrometer, luxmeter, $\mathrm{pH}$ meter, kamera digital, meteran, alat tulis menulis, kotak sampel dan oven. Bahan yang digunakan adalah jamur Basidiomycota, alkohol $70 \%$ dan tally sheet.

Metode yang digunakan adalah metode jelajah (Cruise method) dengan menyusuri lokasi penelitian, dan mengambil specimen jamur di kawasan Arboretum. Jamur yang ditemukan disetiap titik pengamatan dicatat ciri-ciri morfologinya (ukuran, warna, bentuk dan habitat) dan jumlah individu spesies.

Pengkoleksian dilakukan terhadap spesies jamur yang telah teridentifikasi di lapangan maupun yang belum teridentifikasi guna pengamatan lebih lanjut. Identifikasi jamur Basidiomycota 
dilakukan menggunakan beberapa buku identifikasi jamur dan berdasarkan jurnal hasil penelitian mengenai jamur : Alexopoulos (1952), Hall et al. (2003), David L Largent (1973), Tampubolon (2010), Zoberi (1972) dan Dwidjoseputro (1978).

Data yang dikumpulkan dianalisis kualitatif berdasarkan ciri-ciri morfologi jamur Basidiomycota yaitu ukuran basidiokarp (tubuh), warna basidiokarp, bentuk basidiokarp yang meliputi tudung (pileus), mangkok (volva), tangkai (stipe), cincin (annulus), himenium, bilah (lamella), pola koloni atau soliter dan juga habitat (tanah/serasah, kayu mati dan pohon hidup).

\section{HASIL DAN PEMBAHASAN}

Hasil

Berdasarkan hasil penelitian yang telah dilakukan dikawasan arboretum Fakultas Kehutanan Universitas Lancang Kuning ditemukan 25 jenis jamur Basidiomycota. Ordo Agaricales merupakan kelompok yang mendominasi dalam lokasi penelitian, karena jumlah famili dan spesiesnya paling banyak ditemukan dalam penelitian ini . Famili dari ordo Agaricales famili yang mendominasi kelompok jamur Basidiomycota.

Tabel 1. Jamur Basidiomycota yang ditemukan di arboretum Fakultas Kehutanan Universitas Lancang Kuning

\begin{tabular}{|c|c|c|c|c|}
\hline No & Ordo & Famili & Genus & Spesies \\
\hline 1 & Auriculareales & Auriculariaceae & Auricularia & Auricularia auricula \\
\hline 2 & Aphylloporales & Schizophylaceae & Auricularia & Schyzophylum commune \\
\hline \multirow{13}{*}{3} & \multirow{13}{*}{ Agaricales } & Clavariaceae & Ramariopsis & Ramariopsis kunzei \\
\hline & & \multirow{3}{*}{ Agaricaceae } & Agaricus & Agaricus crocopeplus \\
\hline & & & Lepiota & Lepiota sp \\
\hline & & & Lycoperdon & Lycoperdon pyriforme \\
\hline & & Crepidotaceae & Crepidotus & Crepidotus sp \\
\hline & & \multirow{2}{*}{ Mycenaceae } & Mycena & Mycena incata \\
\hline & & & Mycena & Mycena sp \\
\hline & & \multirow{5}{*}{ Marasmiaceae } & Marasmius & Marasmius candidus \\
\hline & & & Marasmius & Marasmius andrasaceus \\
\hline & & & Marasmius & Marasmius elegans \\
\hline & & & Marasmius & Marasmius sp1 \\
\hline & & & Marasmius & Marasmius sp2 \\
\hline & & Tricholomataceae & Collybia & Collybia $s p$ \\
\hline \multirow{8}{*}{4} & \multirow{8}{*}{ Polyporales } & \multirow{4}{*}{ Polyporaceae } & Polyporus & Polyporus $s p$ \\
\hline & & & Lignosus & Lignosus rhinocerus \\
\hline & & & Ganoderma & Ganoderma apllanatum \\
\hline & & & Ganoderma & Ganoderma sp \\
\hline & & \multirow{2}{*}{ Fomitopsidae } & Fomitopsis & Fomitopsis cajanderi \\
\hline & & & Fomitopsis & Fomitopsis finicola \\
\hline & & \multirow{2}{*}{ Meripilaceae } & Grivola & Grivola frondosa \\
\hline & & & Grivola & Grivola sp \\
\hline
\end{tabular}




$5 \quad$ Hymenochaetales Hymenochaetaceae \begin{tabular}{ll}
\hline \multirow{2}{*}{ Coltricia } & Coltricia perennis \\
\cline { 3 - 3 } &
\end{tabular}

Deskripsi jenis jamur Basidiomycota Kehutanan Universitas Lancang Kuning yang ditemukan di Arboretum Fakultas dapat dilihat pada tabel 2 berikut :

\section{Tabel 2. Deskripsi jenis-jenis jamur Basidiomycota yang ditemukan di arboretum Fakultas Kehutanan Universitas Lancang Kuning.}
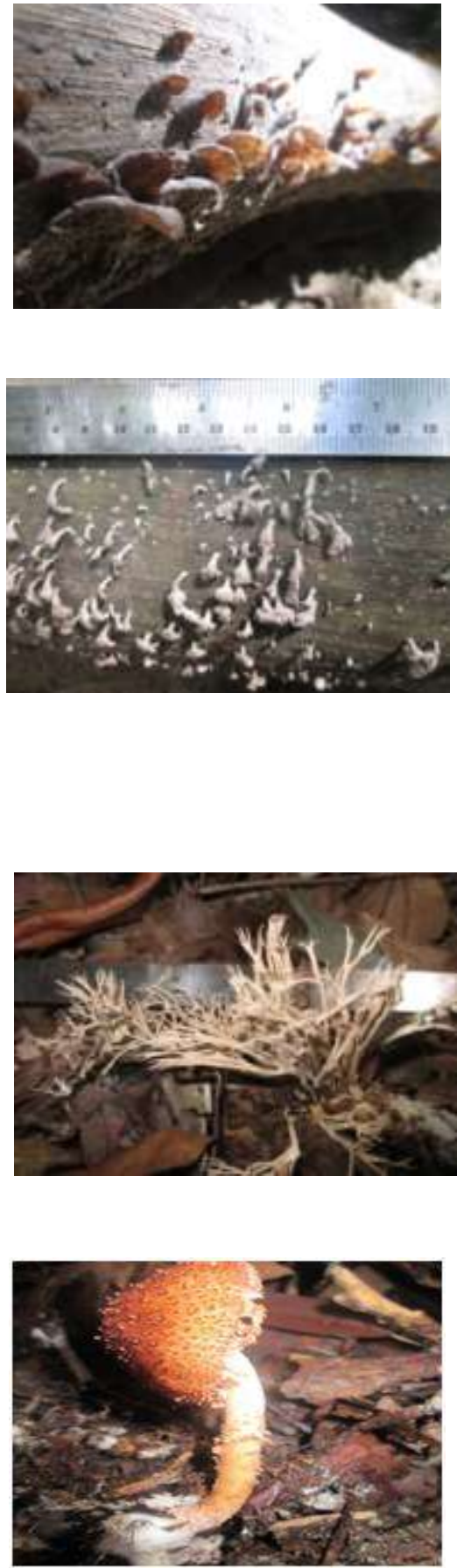

1. Auricularia auricula

Deskripsi: Letak tubuh buah pileus pada posisi lateral, tubuh buah seperti jelly, permukaan berlekuk lekuk dan licin dengan tepi tubuh buah yang licin smooth, berbentuk cekung, berwarna kuning - coklat, berdiameter $2-2,5 \mathrm{~cm}$ dan pangkal tubuh buah langsung melekat pada substrat dan tipe akar semu rhizoid.

Habitat: Tumbuh berkoloni pada batang kayu lapuk/mati. Edibilitas: Dapat dikonsumsi sebagai bahan makanan.

\section{Schizophylum commune}

Deskripsi : Tubuh buah seperti kipas, berdaging dan elastis, diameter tudung 1-3 cm, berwarna abu-abu, permukaan tudung berbulu panjang, bagian tepinya terbelah, bentuk bilah bercabang ketepi, letak tubuh buah pileus pada posisi sessile, permukaan atas kasar berserabut lunak, permukaan bawah seperti gabus, tepi tubuh buah berserabut. Tangkai tubuh buah stipe pendek, bersisik reticulated berwarna kuning dan tipe akar semu.

Habitat: Tumbuh koloni pada kayu lapuk.

Edibilitas: Tidak menarik untuk dimakan karena teksturnya liat dan kering.

\section{Ramariopsis kunzei}

Deskripsi: Tubuh buah tegak atau menjalar, bercabang, seperti karang tinggi $2,5-10 \mathrm{~cm}$, dan lebar $3-8 \mathrm{~cm}$. cabang berwarna putih hingga krem, putih, permukaan licin, tekstur tidak padat ujung tumpul. Tangkai pendek, rapuh, bagian dasar berbulu, berwarna putih, rapuh.

Habitat :Pada tanah/serasah, kayu lapuk hidup tersebar hingga padat berkelompok.

Edibilitas: Tidak berbahaya, tidak berdaging dan tidak berasa.

\section{4. $\quad$ Agaricus crocopeplus}

Deskripsi : Diameter tudung berukuran $3-7 \mathrm{~cm}$, bentuk tudung bulat, cembung, berwarna cokelat muda, namun di bagian tengah berwarna cokelat tua, terdapat bintikbintik berwarna lebih tua yang tersebar di permukaan tudung dan juga tangkai, permukaan tudung agak kasar. Ukuran tangkai $2-4 \times 0.5 \mathrm{~cm}$, berwarna cokelat.

Habitat : Hidup pada serasah/humus, hidup dalam kelompok kecil

Edibilitas: Tidak diketahui. 

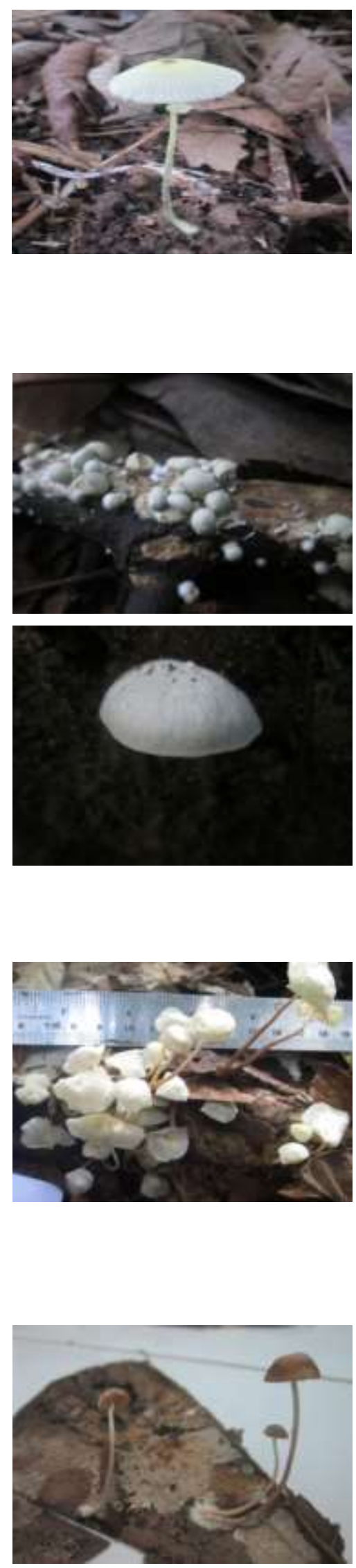

\section{Lepiota $s p$}

Deskripsi : Tudung berdiameter 1,5-4 cm, bentuk payung, oval kemudian cembung, permukaan kering, licin, tanpa sisik, berwarna kekuningan, coklat kemerahan pada bagian tengah. Daging buah tipis, putih. berlamella, lapisan himenium (gill) melekat pada tangkainya (adnate), tertutup, berwarna putih. Panjang tangkai $6 \mathrm{~cm}$, tebal $2-5 \mathrm{~mm}$, memiliki cincin(annulus) pada bagian atas.

Habitat : Serasah, tanah berhumus, hidup berkelompok kecil.

Edibilitas: Tidak dikonsumsi, sebagian jenisnya beracun.

\section{Lycoperdon pyriforme}

Deskripsi : Tubuh buah berbentuk buah pir hingga bulat, berwarna putih, tekstur lembut, berdiameter $1,5-4 \mathrm{~cm}$, tinggi $2-3 \mathrm{~cm}$, tidak bertangkai. Tubuh buah padat dan bagian dalamnya berwarna putih saat muda dan berwarna kuning kehijauan ketika dewasa.

Habitat : Kayu lapuk, tumbuh berkelompok.

Edibilitas: Dapat dikonsumsi ketika buah masih muda.

\section{Crepidotus $s p$}

Deskripsi: Tubuh buah pileus terletak pada posisi sessile, Tudung berdiameter $1-2 \mathrm{~cm}$, permukaan licin smooth dan transparan diselimuti lendir, tepi tubuh buah polos even, berbentuk cembung, berwarna putih terang dan transparan, tidak memiliki tangkai buah stipe licin smoth dengan tubuh buah melekat pada substrat dan tipe akar semu rhizoid.

Habitat: Soliter, tumbuh pada tanah dan substrat pohon

Edibilitas:Tidak diketahui

\section{Mycena incata}

Deskripsi : Tudung berdiameter 2-4 cm, berwarna putih hingga kuning, cembung hingga bagian tepi, bagian tengah putih kilat, kadang-kadang sedikit cembung (umbonate), permukaan tudung licin, melekat pada tangkainya (adnate), Lamella/himenium jarang. Tinggi tangkai 3-8 x 0,2-1 cm, permukaanya berwarna putih hingga kuning, permukaan licin. Daging buah berwarna keputihan. Berbau seperti lobak.

Habitat : Serasah, kayu lapuk, hidup menyebar atau berkelompok.

Edibilitas : Tidak diketahui.

\section{Mycena sp}

Deskripsi : Tudung berdiameter $2-4 \mathrm{~cm}$, seperti lonceng hingga cembung, berwarna putih hingga kuning kemerahan, permukaan licin, bergaris-garis, transparan. Daging buah lembut, sangat tipis dan rapuh. Lapisan himenium (gill) melekat pada tangkainya, berwarna sama dengan tudung. Letak tangkai persis di tengah tudung (center) dengan tinggi $7-10 \mathrm{~cm}$, lebar $0,2-0,3$ $\mathrm{mm}$, berwarna coklat kemerahan, semakin pucat ke 

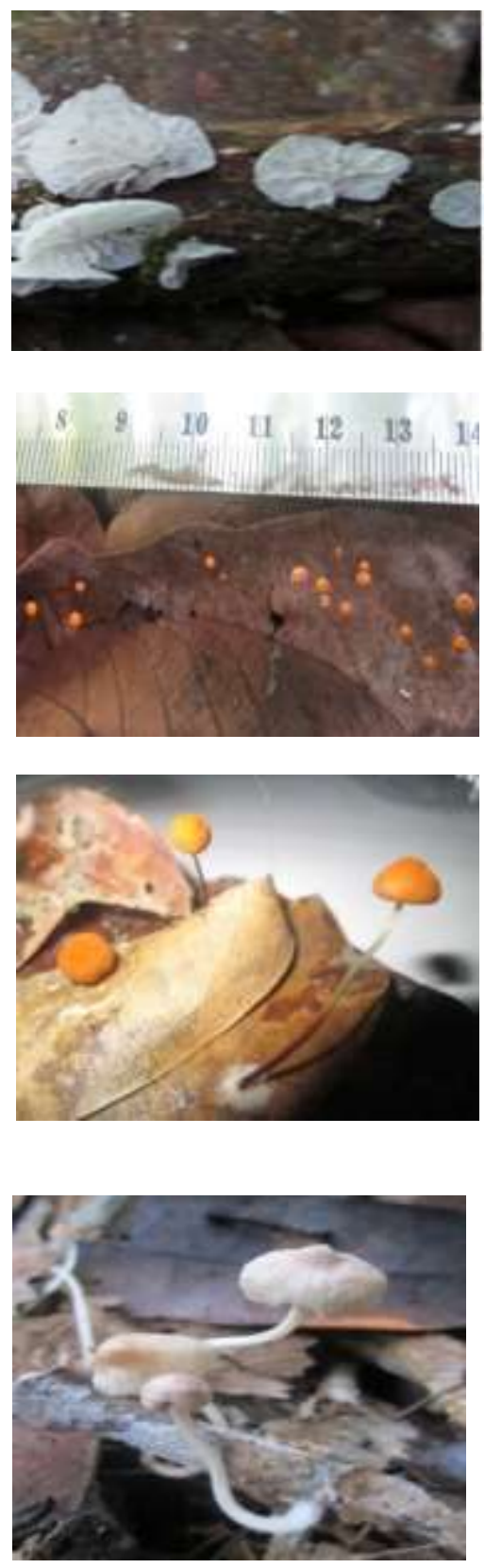

arah tudung, permukaan licin, rapuh.

Habitat : Serasah, hidup berkelompok.

Edibilitas : Tidak menarik untuk dikonsumsi karena teksturnya rapuh.

\section{Marasmius candidus}

Deskripsi : Tudung berukuran kecil 2-10 mm, cembung dan pada bagian tengahnya sedikit cekung, bergarisgaris atau berkerut, berwarna coklat kemerahan atau coklat pucat. Bagian himenium (gill) berwarna coklat. Tangkai seperti rambut, kaku,berwarna coklat atau hitam.

Habitat : Tersebar pada serasah

Edibilitas: Tidak diketahui.

\section{Marasmius andrasaceus}

Deskripsi : Tudung berukuran kecil 2-10 mm, cembung dan pada bagian tengahnya sedikit cekung, bergarisgaris atau berkerut, berwarna coklat kemerahan atau coklat pucat. Bagian himenium (gill) berwarna coklat. Tangkai seperti rambut, kaku,berwarna coklat atau hitam.

Habitat : Tersebar pada serasah

Edibilitas: Tidak diketahui.

\section{Marasmius elegans}

Deskripsi : Tudung berwarna oranye gelap atau cokelat oranye, seperti helm, diameternya berukuran 0,6 - 1,5 $\mathrm{cm}$, permukaannya seperti beludru. Himenium berwarna putih, melekat pada tangkai. Panjang tangkai $3-5 \mathrm{~cm}$, tebalnya $0,1-0,3 \mathrm{~cm}$, berwarna putih kemerahan, putih kearah ujung tangkai, lunak, agak transparan.

Habitat : Hidup soliter/kelompok kecil pada tumpukan serasah dan kayu lapuk.

Edibilitas: Tidak diketahui.

\section{Marasmius sp1}

Deskripsi : Tudung berdiameter 1,5-3,5 cm, bentuk cembung, permukaan licin atau berkerut, transparan, bergaris-garis, putih pucat atau keabuan hingga kuning sedikit abu-abu, kekuningan ketika dewasa. Daging buah sangat tipis, lembut. Lapisan himenium (gill) melekat pada tangkainya (adnate), lebar, berwarna putih. Panjang tangkai $3-7 \mathrm{~cm}$, tebal $2-5 \mathrm{~mm}$, sama atau lebih besar bagian dasar, pipih, licin, berwarna sama dengan tudung. Bagian dasar keabuan, berambut. Habitat : Serasah, kayu lapuk hidup, tersebar hingga berkelompok.

Edibilitas: Tidak diketahui. 

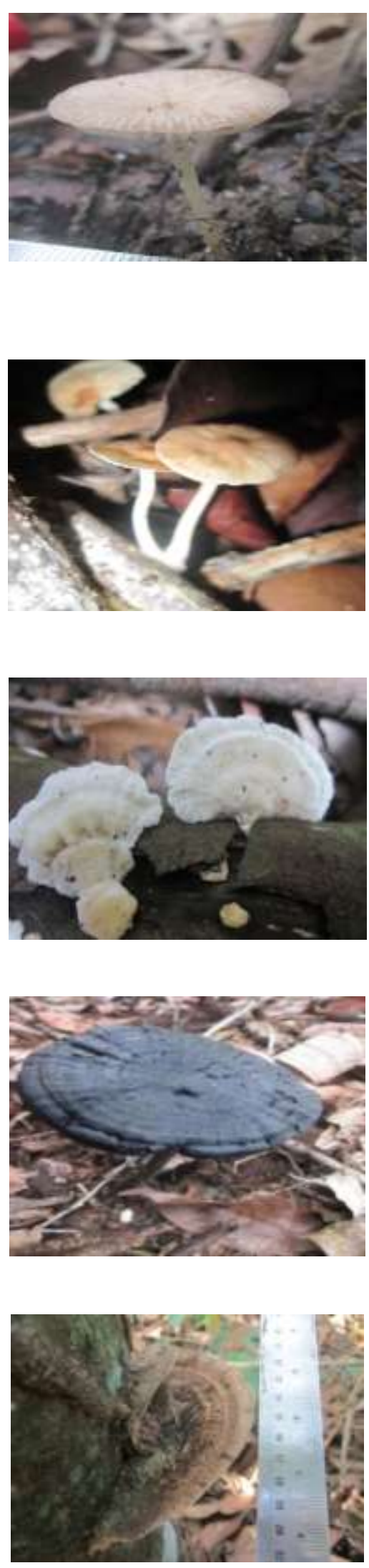

\section{Marasmius sp2}

Deskripsi : Tudung berdiameter $1-2 \mathrm{~cm}$, berwarna putih abu-abu kecokelatan, cembung, pipih, sedikit cekung dibagian tengah tudung, bergaris-garis membujur rapat dari bagian tepi hingga tengah tudung, bagian tepi agak tidak rata. Himenium berwarna sama dengan tudung, menempel pada tangkai. Panjang tangkai $2-4 \mathrm{~cm}$, tebalnya $0,1-0,2 \mathrm{~cm}$, berwarna putih. Habitat : Pada serasah, kayu lapuk, hidup tersebar atau dalam kelompok kecil.

Edibilitas: Tidak diketahui

\section{Collybia $s p$}

Deskripsi : Tudung berdiameter 2-4 cm, berbentuk payung, cembung dan pipih, permukaan licin, tekstur halus berwarna putih hingga cream, terdapat sedikit tonjolan kecil ditengah tudung. Lapisan himenium (gill) terbuka, berwarna putih. Panjang tangkai $2-3 \mathrm{~cm}$, tebal 2-4 $\mathrm{mm}$ permukaan licin, berwarna sama dengan tudung.

Habitat : Kayu lapuk, hidup dalam kelompok kecil.

Edibilitas : Dapat dikonsumsi.

\section{Polyporus sp}

Deskripsi :Tubuh buah keras dan liat, rapuh bila kering. Memiliki tangkai sederhana yang pendek. Tudung berdiameter $2-5 \mathrm{~cm}$, berbentuk kipas, permukaannya licin, mengkilat, berwarna putih dengan zona garis melintang berwarna keungu-unguan. Permukaan himenium berpori, berwarna putih hingga krem. Jamur ini tidak dikonsumsi.

Habitat : Hidup berkelompok pada kayu lapuk. Edibilitas: Tidak dikonsumsi.

\section{Lignosus rhinocerus}

Deskripsi : Tudung berwarna cokelat gelap higga hitam, bagian tengah tudung sedikit cekung hampir berbentuk corong, melengkung ke arah tepi, bagian tepi tidak rata, berukuran $4-7 \mathrm{~cm}$, tebalnya $2-4 \mathrm{~mm}$. Keras seperti kayu, Himeniumnya berpori dan berwarna sama dengan tudung. Tangkai berwarna abu-abu, panjang tangkai 3 $10 \mathrm{~cm}$.

Habitat : Pada tanah, Hidup hampir selalu soliter. Edibilitas: Tidak dikonsumsi.

\section{Ganoderma apllanatum}

Deskripsi : Tubuh buah berdiameter $4-8 \mathrm{~cm}$, tidak bertangkai (sessil), berbentuk kipas, seperti papan, terdapat zona pertumbuhan (bergaris konsentris), berwarna putih kecoklatan. Bagian tepi tubuh berwarna putih, keras berpori. langsung melekat pada substrat, tipe akar semu rhizoid.

Habitat : Tumbuh sebagai parasit pada pohon hidup.

Edibilitas : Tidak dikonsumsi karena teksturnya keras seperti kayu. 

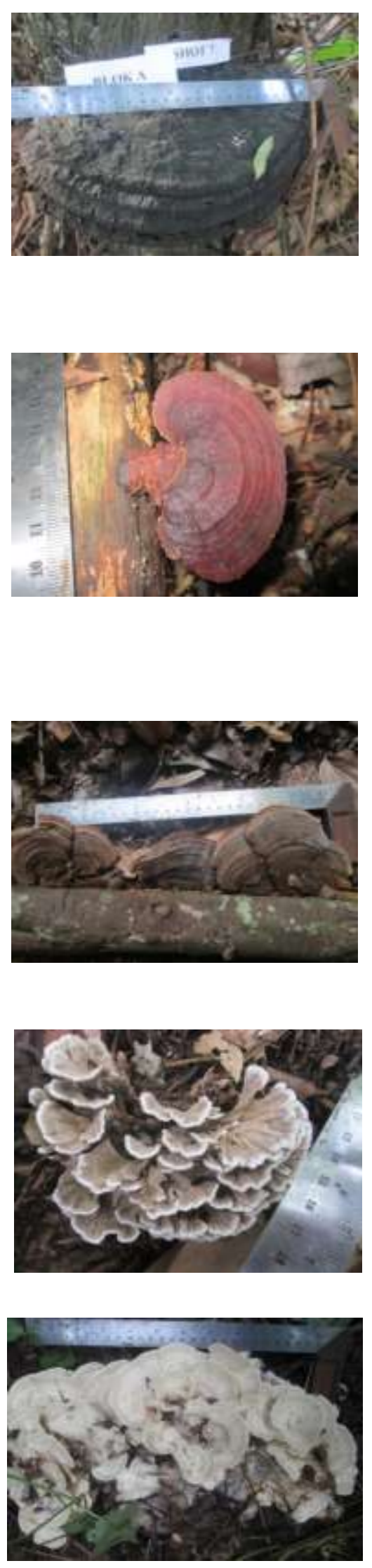

\section{Ganoderma sp}

Deskripsi : Tubuh buah berbentuk setengah lingkaran, berukuran $30 \mathrm{~cm}$, tidak bertangkai, bertekstur seperti kayu, berwarna hitam. Bagian bawah tubuh buah berwarna putih atau abu-abu, berpori, tidak memiliki pangkal tangkai buah stipe sehingga tubuh buah melekat pada substrat dan tipe akar semu rhyzoid.

Habitat : Hidup soliter sebagai parasit pada batang pohon hidup.

Edibilitas : Tidak dikonsumsi, karena teksturnya yang keras berkayu.

\section{Fomitopsis cajanderi}

Deskripsi : Tubuh buah keras seperti kayu, berbentuk ginjal atau kuku, berdiameter $2,5-10 \mathrm{~cm}$, tebalnya $0,2-$ $2 \mathrm{~cm}$. Permukaan tudung halus, berbentuk seperti papan, warnanya bervariasi yakni, merah muda hingga merah, cokelat kemerahan, cokelat muda, dan cokelat kehitaman, bagian tepi yang berlekuk tipis. Daging buah merah muda hingga kemerahan, atau cokelat kemerahan, agak lembut ketika masih muda. Jamur ini tidak memiliki tangkai.

Habitat : Hidup berkelompok pada kayu lapuk.

Edibilitas: Tidak dikonsumsi.

\section{Fomitopsis finicola}

Deskripsi : Tubuh keras, tekstur berkayu, Tudung berdiameter $6-25 \mathrm{~cm}$, tebal $3 \mathrm{~cm}$, berbentuk kipas atau setengah lingkaran, kuning tua atau kemerahan dan berwarna coklat karat atau coklat kehitaman ke arah dasar cap, terdapat garis konsentris. Jamur ini tidak bertangkai.

Habitat : Hidup soliter atau berkelompok pada kayu lapuk/mati.

Edibilitas : Tidak dikonsumsi.

\section{Grivola frondosa}

Deskripsi: Berbentuk sekumpulan tudung cokelat keabuan berlekuk/ bergelombang, sisi atas berwarna coklat sementara sisi bawah berwarna sedikit cream. Bentuknya seperti karang. Tidak bertangkai langsung menempel pada tanah, diameter tubuh $7-8 \mathrm{~cm}$.

Habitat : Tanah, tumbuh soliter.

Edibilitas : Dapat dikonsumsi, biasanya di ekstrak menjadi obat anti kanker.

\section{Grivola $s p$}

Deskripsi : Berbentuk sekumpulan tudung bertingkat cokelat keabuan berlekuk/ bergelombang, sisi atas berwarna cream kecoklatan. Bentuknya seperti karang. Tidak memiliki tangkai, langsung menempel pada tanah, diameter tubuh buah buah $10-30 \mathrm{~cm}$. hidup disubtrat pohon.

Habitat : Tanah, tumbuh soliter dan berkelompok kecil. Edibilitas : Dapat dikonsumsi sebagai obat. 

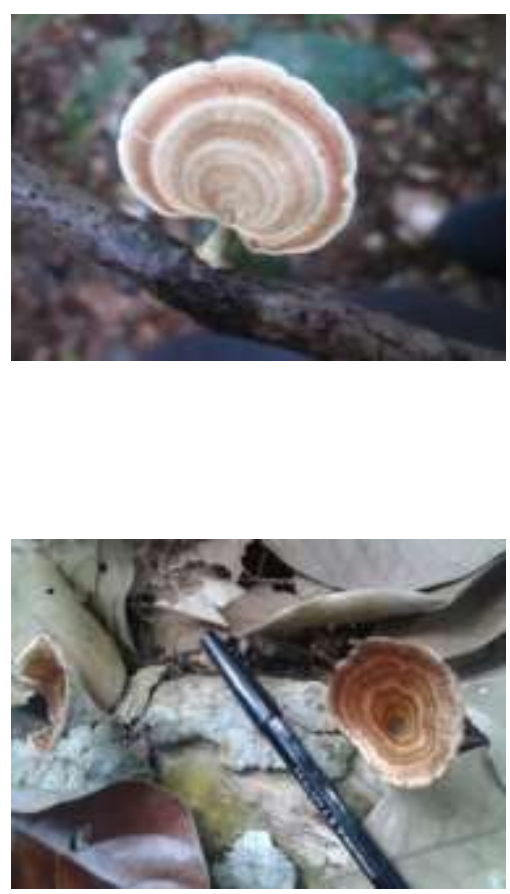

24. Coltricia perennis

Deskripsi : Tubuh buah datar atau sedikit berbentuk corong, tipis, tekstur seperti kulit, permukaannya seperti beludru, bergaris-garis konsentris, permukaan licin, berwarna putih kecoklatan atau abu-abu ketika. Berdiameter 2-7 cm Bagian tepi tubuh tipis dan bergelombang. Stipe pendek 1 hingga $3 \mathrm{~cm}$, silindris. Permukaan bawah bawah berpori. Tipe akar insert rizoid.

Habitat : Tumbuh soliter atau bergerombol pada kayu lapuk.

Edibilitas : Tidak diketahui.

\section{Coltricia cinamomea}

Deskripsi : Tudung berdiameter 5-7 cm, tekstur liat, berwarna coklat, kuning kecoklatan, coklat gelap, mengkilap dengan garis-garis konsentris, pada bagian tengah lengkung seperti corong. hemineum berwarna coklat dengan pori-pori. Panjang tangkai 1-2 cm, letaknya ditengah cap, berwarna coklat.

Habitat : Hidup soliter pada kayu lapuk.

Edibilitas : Tidak diketahui.

\section{Pembahasan}

Dari 25 jenis jamur Basidiomycota yang teridentifikasi adalah ordo Agaricales, Polyporales, Aphylloporales, Auriculareales dan Hymenochaetales. Ordo Agaricales merupakan ordo yang paling banyak ditemukan dalam penelitian ini. Famili dari ordo Agaricales antara lain Agaricaceae, Clavariaceae, Mycenaceae, Marasmiaceae, Crepidotaceae, dan Tricholomateceae, dimana Marasmiaceae merupakan famili yang mendominasi di ordo ini. Ordo Agaricales beradaptasi dengan baik terhadap lingkungan Arboretum Fakultas Kehutanan serta sesuai sebagai habitat bagi ordo ini. Ordo Agaricales sendiri adalah kelompok jamur Basidiomycota makroskopis yang paling familiar dengan bentuk seperti payung (Arora 1986, dalam Tampubolon 2010). Anggota ordo Agaricales sangat banyak dan kompleks. Dalam beberapa penelitian, anggota ordo ini selalu ditemukan dan sering dengan jumlah anggota terbesar yang ditemukan dalam penelitian-penelitian tersebut.

Berdasarkan tabel 1 diatas dapat diketahui bahwa kayu lapuk menjadi habitat yang dominan bagi kebanyakan spesies jamur Basidiomycota di areal penelitian. Pada penelitian ini ditemukan 10 spesies jamur (40\%) yang hidup hanya pada kayu lapuk dan 7 spesies jamur Basidiomycota (28\%) yang hidup hanya pada tumpukan serasah/tanah. Beberapa spesies jamur Basidiomycota dapat hidup pada lebih dari satu habitat, 
antara lain hidup pada kayu lapuk dan serasah/tanah ada 7 spesies (28\%) serta hidup pada kayu lapuk dan kayu/pohon hidup ada 1 spesies (4\%).

Kondisi ini menunjukkan bahwa beberapa spesies jamur Basidiomycota dapat hidup pada lebih dari satu habitat. Pernyataan Asnah (2010) dalam Tampubolon (2010) bahwa jamur Basidiomycota dapat tumbuh di banyak habitat dari artik hingga tropis, dan beberapa jamur Basidiomycota menunjukkan habitat spesifik. Umumnya jamur Basidiomycota makroskopis tumbuh di atas kayu lapuk, serasah/tanah, daun, dan kotoran hewan, serta ada juga yang tumbuh pada jamur yang telah membusuk.

Jamur Basidiomycota yang ditemukan di arboretum Fakultas Kehutanan Universitas Lancang Kuning pada umumnya merupakan spesies jamur pelapuk kayu dan serasah. Hal ini dikarenakan sebagian besar jamur yang ditemukan dalam penelitian ini hidup pada kayu lapuk dan serasah. Dengan demikian dapat diketahui bahwa sebagian besar spesies jamur Basidiomycota yang ditemukan berperan sebagai dekomposer dalam jaring-jaring makanan di ekosistem. Hal ini sesuai dengan pernyataan Suharna
(1993) dalam Sari (2015) bahwa jamur berperan sebagai dekomposer bersama dengan bakteri dan beberapa spesies protozoa, sehingga banyak membantu proses dekomposisi bahan organik untuk mempercepat siklus materi dalam ekosistem hutan. Munir (2006) juga menyatakan bahwa kelompok jamur makroskopis merupakan kelompok utama organisme pendegradasi lignoselulosa, karena mampu menghasilkan enzim-enzim pendegradasi lignoselulosa seperti selulase, ligninase, dan hemiselulase yang mendegradasi komponen dinding sel tumbuhan dan melepaskan nutrisi hasil metabolismenya kembali ke lingkungan.

Pendapat Fuhrer (2011) dalam Syafrizal (2014) yang menyatakan bahwa jamur makroskopis yang terdapat di hutan umumnya tumbuh pada pohon mati dan kayu dan serasah daun. Jamur adalah organisme yang tidak berklorofil, sehingga dalam pertumbuhannya jamur memerlukan zatzat makanan dari proses pelapukan organisme lain yang telah mati. Jamur tersebut memiliki peran penting sebagai dekomposer dalam ekosistem. Hal ini sesuai dengan pendapat Campbell, dkk (2003) dalam Syafrizal (2014) yang 
menyatakan bahwa jamur bersama bakteri merupakan pengurai utama yang dapat mempengaruhi keseimbangan ekosistem dengan menjaga tersedianya nutrien anorganik yang sangat penting bagi pertumbuhan tumbuhan di ekosistem.

Beberapa spesies jamur Basidiomycota yang ditemukan di areal penelitian juga bersifat parasit bagi kayu/pohon yang masih hidup. Hal ini sesuai dengan pernyataan Mc Kane dan Kandel (1996) dalam Sari (2015) bahwa beberapa spesies jamur makroskopis bersifat parasit bagi tumbuhan atau hewan. Ditemukan dua spesies jamur pada kayu/pohon yang masih hidup. Spesies tersebut adalah Ganoderma aplanatum dan Ganoderma sp. Hal ini sesuai dengan hasil penelitian yang dilakukan Tampubolon (2010) juga menemukan bahwa Ganoderma applanatum hidup sebagai parasit pada batang pohon yang masih hidup.

\section{Kesimpulan dan Saran}

\section{Kesimpulan}

Arboretum yang dimiliki oleh Fakultas Kehutanan Universitas Lancang Kuning berada di kawasan hutan dataran rendah. Berdasarkan hasil penelitian yang telah dilakukan, dapat disimpulkan bahwa ditemukan 25 jenis jamur Basidiomycota yang terdiri dari 5 Ordo dan 12 Famili. Ordo Agaricales merupakan kelompok yang mendominasi dalam lokasi penelitian. Jamur Basidiomycota yang ditemukan umumnya hidup pada kayu lapuk dan serasah, serta sebagian kecil hidup pada pohon hidup. Dengan ditemukannya pohon ini maka dapat meberikan informasi tentang keanekaragaman jamur Basidiomycota di arboretum Fakultas Kehutanan Universitas Lancang Kuning

\section{DAFTAR PUSTAKA}

Alexopoulos, C. J. 1952. Introductory Mycology, Second Edition. John Wiley and Sons, Inc. Canada.

Asnah, 2010. Inventarisasi Jamur Makroskopis di Ekowisata Tangkahan Taman Nasional Gunung Leuser Kabupaten Langkat Sumatera Utara. [Tesis]. Program Studi Magister Biologi FMIPA USU. USU Repository. Medan.

Aswadi, dkk. 2012. Inventarisasi Jamur Makroskopis di Hutan Adat Sungai Kantuk, Kabupaten Sintang, Kalimantan Barat disajikan dalam Seminar Pendidikan Karakter dan Hasil Penelitian IImiah: Eksplorasi Hutan Adat Sungai Kantuk Kabupaten Sintang oleh Mahasiswa Pendidikan Biologi FKIP Untan, Universitas Tanjungpura, Pontianak. 
Dwidjoseputro, D. $1978 . \quad$ Pengantar Mikologi, Edisi Kedua. Penerbit Alumni. Bandung.

FWI. 2013. Potret Keadaan Hutan Indonesia Periode 2000-2009. Bogor, indonesia

Gunawan, A.W. 2001. Usaha Pembibitan Jamur. Jakarta: Penebar Swadaya.

Hall, I. R., S. L. Stephenson, P. K. Buchanan, W. Yun, dan A. L. J. Cole. 2003. Edible and Poisonous Mushrooms of the Worlds. Timber Press, Inc. Cambridge..

Hayati, N. 2013. Karakterisasi Morfologi Dan Anatomi Jamur Ektomikorhiza Scleroderma Spp. Pada Tanaman Melinjo (Gnetum gnemon L.) Di Kabupaten Pacitan. Semarang. [Jurnal]. Tadris Biologi Fakultas Tarbiyah IAIN Walisongo.

Khosuma, A.2012. Keanekaragaman Jamur Makroskopis Pada Altitud Berbeda Di Sepanjang Jalur Pendakian Gunung Bawakaraeng. Makassar. [Skripsi]. Fakultas Matematika Dan IImu Pengetahuan Alam. Universitas Hasanuddin.

Largent, David L. 1973. How to Identify Muahrooms To Genus I: Macroscopic Features.

McKnight, K.H. dan Vera B.M. 1987. Mushrooms. New York: Houghton Mifflin Company.

McKane, L. dan J. Kandel. 1996. Microbiology: Essentials and Applications. McGraw-Hill. New York.

Munir, E. 2006. Pemanfaatan Mikroba dalam Bioremediasi: Suatu Teknologi
Alternatif untuk Pelestarian Lingkungan. Pidato Pengukuhan Jabatan Guru Besar Tetap dalam Bidang Mikrobiologi FMIPA USU. USU Repository. Medan.

Nasution, Hasbullah. 2015. Inventarisasi Famili Dipterocarpaceae Di Arboretum Fakultas Kehutanan Universitas Lancang Kuning. Fakultas Kehutanan UNILAK

Risnawardiana, et al,. 2015. Inventarisasi jamur Basidiomycetes Makroskopis Di Kawasan Kampus Universitas Hasanuddin Tamanlarea Makassar.

Sari, et al,. 2015. Jenis-Jenis Jamur Basidiomycetes di Hutan Bukit Beluan Kecamatan Hulu Gurung Kabupaten Kapuas Hulu. [Jurnal]. Pontianak. Program Studi Biologi, Fakultas MIPA. Universitas Tanjungpura.

Syafrizal, S. 2014. Inventarisasi Jamur Makroskopis Di Hutan Adat Kantuk Dan Implementasinya Dalam Pembuatan Flipbook. [Skripsi]. Pontianak. Program Studi Pendidikan Biologi Jurusan Pmipa. Universitas Tanjungpura.

Tampubolon, et al,. 2010. Keanekaragaman Jamur Makroskopis di Hutan Pendidikan Universitas Sumatera Utara Desa Tongkoh Kabupaten Karo Sumatera Utara. [Jurnal]. Medan. Program Studi Kehutanan, Fakultas Pertanian, Universitas Sumatera Utara.

Waluyanti, Maila. 2008. Implementasi Hasil Penelitian Biologi (Studi Keanekaragaman Jamur Basidiomycota) Sebagai Sumber 
Belajar materi Fungi SMA $X$ Semester Ganjil Kurikulum Ktsp. [Jurnal] Fakultas Keguruan Dan IImu Pendidikan Universitas Sebelas Maret Surakarta.

Wijaya, Kesuma. 2007. Komposisi dan Struktur Pemudaan Semai dan Pancang Di Arboretum Dipterocarpaceae Fakultas Kehutanan UNILAK. Fakultas Kehutanan Unilak.

Zoberi, M. H. 1972. Tropical Macrofungi: Some Common Species. The Macmillan Press, Ltd.London. 